\title{
High Variation in Pathogenicity of Genetically Closely Related Strains of Xanthomonas albilineans, the Sugarcane Leaf Scald Pathogen, in Guadeloupe
}

\author{
P. Champoiseau, J.-H. Daugrois, I. Pieretti, S. Cociancich, M. Royer, and P. Rott
}

\begin{abstract}
First and second authors: Cirad, UPR Multiplication Végétative, Petit-Bourg, Guadeloupe, F-97170 France; and third, fourth, fifth, and sixth authors: Cirad, UMR Agro.M-Cirad-Inra Biologie et Génétique des Interactions Plante-Parasite (BGPI), TA 41/K, Campus International de Baillarguet, Montpellier Cedex 5, F-34398 France.
\end{abstract}

Accepted for publication 1 May 2006.

\begin{abstract}
Champoiseau, P., Daugrois, J.-H., Pieretti, I., Cociancich, S., Royer, M., and Rott, P. 2006. High variation in pathogenicity of genetically closely related strains of Xanthomonas albilineans, the sugarcane leaf scald pathogen, in Guadeloupe. Phytopathology 96:1081-1091.

Pathogenicity of 75 strains of Xanthomonas albilineans from Guadeloupe was assessed by inoculation of sugarcane cv. B69566, which is susceptible to leaf scald, and 19 of the strains were selected as representative of the variation in pathogenicity observed based on stalk colonization. In vitro production of albicidin varied among these 19 strains, but the restriction fragment length polymorphism pattern of their albicidin biosynthesis genes was identical. Similarly, no genomic variation was found among strains by pulsed-field gel electrophoresis. Some variation among

strains was found by amplified fragment length polymorphism, but no relationship between this genetic variation and variation in pathogenicity was found. Only 3 ( $p i l B, r p f A$, and $x p s E$ ) of 40 genes involved in pathogenicity of bacterial species closely related to $X$. albilineans could be amplified by polymerase chain reaction from total genomic DNA of all nine strains tested of $X$. albilineans differing in pathogenicity in Guadeloupe. Nucleotide sequences of these genes were 100\% identical among strains, and a phylogenetic study with these genes and housekeeping genes $e f p$ and ihfA suggested that $X$. albilineans is on an evolutionary road between the $X$. campestris group and Xylella fastidiosa, another vascular plant pathogen. Sequencing of the complete genome of Xanthomonas albilineans could be the next step in deciphering molecular mechanisms involved in pathogenicity of $X$. albilineans.
\end{abstract}

Xanthomonas albilineans is a systemic, xylem-invading pathogen that causes leaf scald of sugarcane (Saccharum interspecific hybrids). This disease occurs in at least 66 countries in the world and can cause severe yield losses (38). Leaf symptoms vary from a single, white, narrow, sharply defined stripe to complete wilting and necrosis of infected leaves, leading to plant death in the most susceptible cultivars. A common symptom in mature cane is the abnormal development of side shoots on stalks (38). Observation of symptoms on leaves or determination of bacterial population density in sugarcane stalk generally are used to assess disease severity and resistance after artificial inoculation of sugarcane $(15,17,26,40)$.

The sugarcane leaf scald pathogen is spread mainly in infected sugarcane cuttings (38), and colonization of the sugarcane stalk is a critical step in disease progress. Pathogenicity of $X$. albilineans, based on the capacity of the pathogen to colonize sugarcane stalks or cause symptoms, varies according to the strain of the pathogen, indicating the existence of different pathotypes within the species $(12,15,28)$. A major toxic compound, called albicidin and specifically produced by $X$. albilineans, plays a key role in pathogenicity $(4,7,8,53)$. Albicidin inhibits DNA replication of proplastids, thus blocking plastid development (8). Albicidin also inhibits DNA replication of Escherichia coli and has antibiotic activity against several gram-positive and gram-negative bacteria $(5,6)$. Hypothetically, albicidin also confers an advantage for sugarcane stalk colonization and disease development (4). However, no relationship was found between variation in toxin biosynthesis and varia-

Corresponding author: P. Rott; E-mail address: philippe.rott@ @irad.fr

DOI: 10.1094/PHYTO-96-1081

(c) 2006 The American Phytopathological Society tion in pathogenicity of $X$. albilineans (12). Another important feature in pathogenicity of $X$. albilineans is the ability of the pathogen to colonize the sugarcane leaf surface and, subsequently, to cause disease (15). Aerial transmission of the pathogen has been shown to occur in several geographic locations in the world, and was associated with recent outbreaks of the disease $(2,13,15)$. In Guadeloupe, two strains of $X$. albilineans differed in their capacity to colonize the sugarcane leaf surface (15).

In $X$. albilineans, high variability has been shown for many different characteristics, such as colony and cell morphology, whole-cell proteins, fatty acid methyl esters, bacteriophage reaction, and immunological properties (serovars) (37). More recently, several genetic variants of the pathogen (haplotypes) and different albicidin production groups (albivars) were identified within the species $(12,17,31)$. Most, if not all, of the disease outbreaks that occurred in the last two decades were attributed to genetic variants of $X$. albilineans identified by restriction fragment length polymorphism with pulsed-field gel electrophoresis (RFLPPFGE) or by repetitive-sequence-based polymerase chain reaction (repPCR) $(17,18)$. Ten PFGE groups (A to J) were described and strains associated with new outbreaks all belonged to PFGE group B. Strains belonging to PFGE group B also were ranked in single genetic groups by amplified fragment length polymorphism (AFLP) and after hybridization of total genomic DNA of $X$. albilineans with DNA probes that harbor albicidin biosynthesis genes (12,31). However, no relationship has been found among genetic, physiological, and serological variability and variation in pathogenicity of the pathogen from different geographic locations, including Guadeloupe (12). Absence of a relationship between variation in albicidin biosynthesis genes and variation in pathogenicity strongly suggested that other virulence factors must play a key role concurrently with albicidin production. 
Mutagenesis by random insertion of transposon Tn5 into genomic DNA has been used successfully for detection and characterization of pathogenicity-related genes in several phytopathogenic bacteria $(19,36,46)$. Similarly, AFLP technique was useful to identify bacterial pathogenicity islands, genes involved in pathogenic fitness, and regulators of virulence of $X$. axonopodis pv. manihotis, after excision, amplification, cloning, and sequence homology analysis of polymorphic bands from AFLP gels (22). Screening of large number of transposon mutants of $X$. albilineans in sugarcane plants would be tedious and consume much time and space because sugarcane is a relatively large plant and disease symptoms appear only several weeks after plant inoculation.

The objective of this study was to investigate the variability in pathogenicity of $X$. albilineans from a single location (Guadeloupe), and to identify putative pathogenicity-associated markers in this pathogen. Various molecular biology methods were investigated, such as RFLP, AFLP, and PCR amplification of known pathogenicity genes, along with physiological tests regarding factors involved in pathogenicity.

\section{MATERIALS AND METHODS}

Bacterial strains and DNA preparation. In 2003, 75 strains of $X$. albilineans were collected in Guadeloupe from different sugarcane-growing locations. Single colonies were isolated on selective agar medium (XAS) after 5 days of growth at $28^{\circ} \mathrm{C}(16)$.
Bacterial strains were stored at $-20^{\circ} \mathrm{C}$ as turbid water suspensions immediately after isolation and retrieved on modified Wilbrink's (MW) agar medium for 3 to 5 days at $28^{\circ} \mathrm{C}$ just before inoculum preparation (35). Serological characteristics of strains were determined as described by Rott et al. (39). For each strain, albicidin production was quantified in vitro by a microbiological assay as described by Champoiseau et al. (12). X. albilineans strain Xa23R1 from Florida (36), X. campestris pv. campestris strain CFBP 5251 (E. Vivien, personal communication), X. campestris pv. vesicatoria strain 91-118 (1), and $X$. arboricola pv. pruni strain CFBP 6653 (9) were grown on MW agar for 3 days at $28^{\circ} \mathrm{C}$.

E. coli strain DH5 $\alpha$ (Life Technologies Inc., Gaithersburg, MD) was grown on Luria-Bertani (LB) agar medium for $24 \mathrm{~h}$ at $37^{\circ} \mathrm{C}(42)$.

Total genomic DNA of bacterial strains was extracted using the Qiagen extraction DNeasy Tissue kit (Qiagen SA, Courtaboeuf, France) according to the manufacturer's recommendations, and adjusted to a final concentration of 20 to $25 \mathrm{ng} / \mu \mathrm{l}$.

Pathogenicity assays. Two greenhouse experiments were set up in Guadeloupe to assess pathogenicity of $X$. albilineans strains by measuring disease severity on leaves and stalk colonization by the pathogen. The experiments were conducted with disease-free tissue-cultured plants of sugarcane cv. B69566, which is susceptible to the leaf scald bacterium (40). Plants were propagated in vitro and transferred to the greenhouse as described by Feldmann et al. (20). Four-week-old plants were grown individually in a

TABLE 1. Characteristics of Xanthomonas albilineans strains from Guadeloupe used in this study

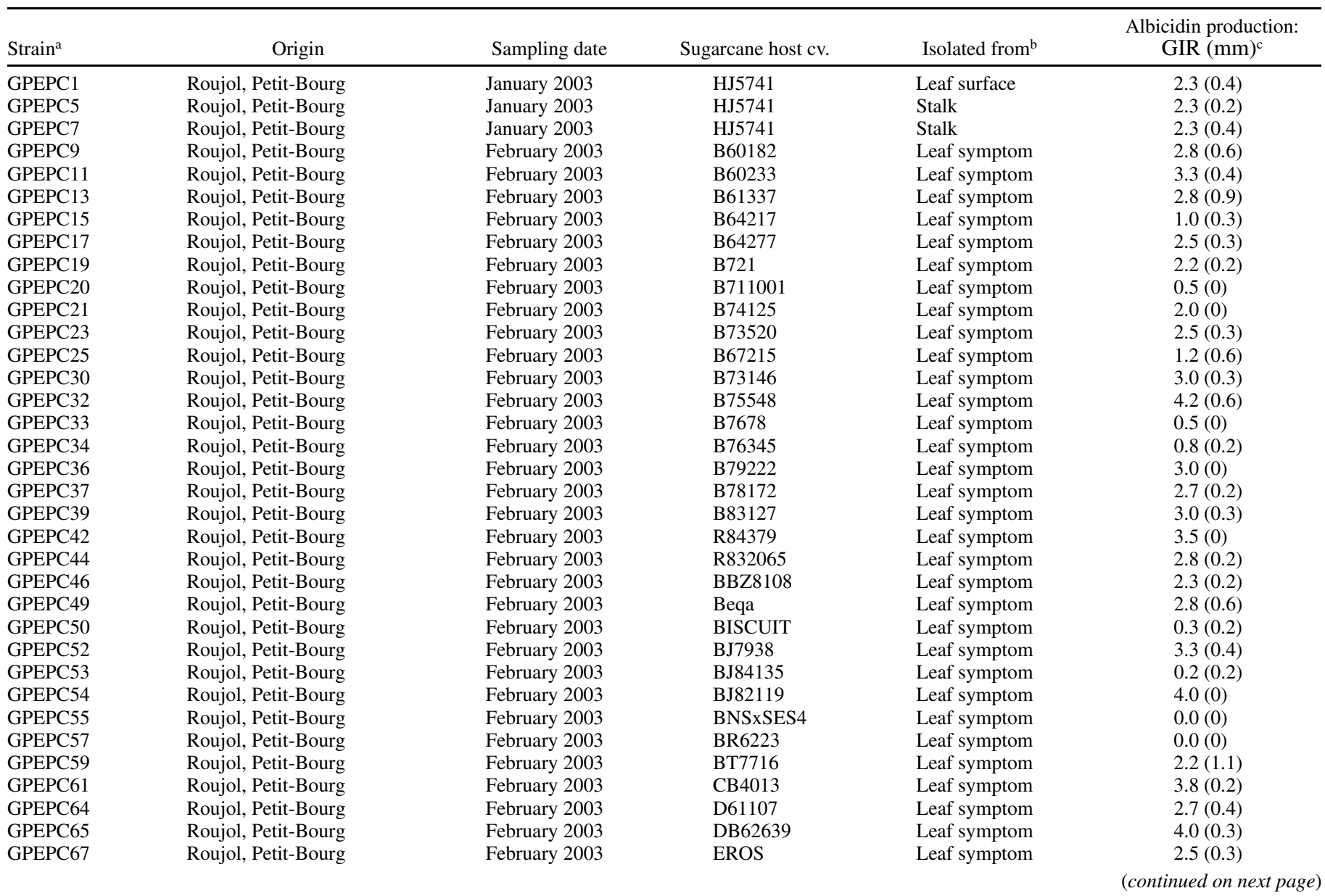

a All strains belonged to serovar I as described by Rott et al. (39).

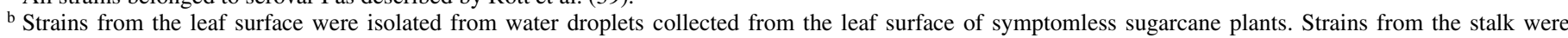
isolated from stalk tissue sampled from diseased sugarcane stalks. Strains from leaf symptoms were isolated from leaves showing necrosis.

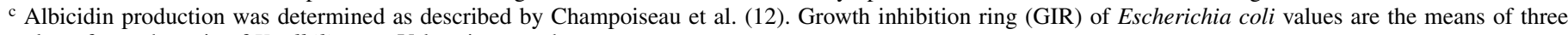
plates for each strain of $X$. albilineans. Values in parentheses are square means. 
greenhouse in 4-liter pots containing an equal volume of field soil and volcanic rock. During plant growth, secondary shoots were systematically removed to keep a single stalk per plant.

Four-month-old plants were inoculated with bacterial suspensions adjusted to $10^{8} \mathrm{CFU} / \mathrm{ml}$ by the decapitation technique as described by Rott et al. (40).

In the first trial (trial A), plants were inoculated with 75 strains of $X$. albilineans (Table 1). Plants then were distributed in the greenhouse using a randomized complete block design with five replications of one plant each. The second trial (trial B) was set up 4 months after trial A, and plants were inoculated with 19 strains of $X$. albilineans that were representative of the variability in pathogenicity identified in trial A (Table 2). After inoculation, plants were distributed in the greenhouse using a randomized complete block design with four replications of four plants each. Control plants inoculated with sterile distilled water were included in both trials to evaluate any naturally occurring cross contamination (17).

Disease severity was assessed as described by Champoiseau et al. (12). Briefly, symptoms were recorded on noninoculated leaves using a symptom severity scale ranging from 0 to 5 , where $0=$ no symptoms, $1=$ one or two pencil-line streaks, $2=$ more than two pencil-line streaks, 3 = leaf chlorosis or bleaching, $4=$ leaf necrosis, and $5=$ death of the plant. Inoculated plants were rated individually based on the score of the leaf showing the most severe symptom. Disease severity (DS) was expressed as DS = $100\left(\left[1 \times N_{1}+2 \times N_{2}+3 \times N_{3}+4 \times N_{4}+5 \times N_{5}\right] / 5 \times N_{T}\right)$, where $N_{i}=$ number of plants with score $i$ and $N_{T}=$ total number of plants. Symptoms were recorded every 2 weeks after inoculation and for 12 weeks in trial A and trial B.

Pathogen populations in different stalk locations were determined 17 and 16 weeks after plant inoculation in trial A and trial $\mathrm{B}$, respectively, by the stalk blot inoculation technique with XAS selective medium, as previously described (12). In both trials, pathogen populations were determined at the location of three shortened stalk internodes that showed reduced growth after mechanical plant inoculation (cut leaves above the growing point) $\left(\mathrm{SL}_{0}\right)$ to control efficiency of plant inoculation. These internodes were attached to the inoculated leaves and, therefore, were considered to be the entry point of the pathogen into the sugarcane stalk. In trial A, pathogen populations also were determined in every two internodes above $\mathrm{SL}_{0}\left(\mathrm{SL}_{+2}, \mathrm{SL}_{+4}, \ldots, \mathrm{SL}_{+\mathrm{X}}\right.$, where $X=$ the last even-numbered internode near the apex of the sugarcane stalk). In trial B, pathogen populations were determined in every internode below $\mathrm{SL}_{0}\left(\mathrm{SL}_{-1}, \mathrm{SL}_{-2}, \ldots, \mathrm{SL}_{-Y}\right.$, where $Y=$ the first internode of the sugarcane stalk near the soil level) and in every internode above $\mathrm{SL}_{0}\left(\mathrm{SL}_{+1}, \mathrm{SL}_{+2}, \ldots, \mathrm{SL}_{+\mathrm{Z}}\right.$, where $Z=$ the last internode near the apex of the sugarcane stalk). Pathogen population densities were assessed in the two trials using a 0-to-4 scale, where $0=$ no bacterial colony in the stalk imprint, $1=1$ to 10 colonies in the stalk imprint, $2=>10$ colonies or confluent growth of bacteria in less than $25 \%$ of the stalk imprint, $3=$ confluent growth of bacteria in 25 to $75 \%$ of the stalk imprint, and $4=$ confluent growth of bacteria in $>75 \%$ of the stalk imprint. Visual identification of $X$. albilineans colonies or confluent growth was verified arbitrarily by serology (39).

TABLE 1. (Continued from preceding page)

\begin{tabular}{|c|c|c|c|c|c|}
\hline Strain $^{\mathrm{a}}$ & Origin & Sampling date & Sugarcane host cv. & Isolated from $^{\mathrm{b}}$ & $\begin{array}{l}\text { Albicidin production: } \\
\text { GIR }(\mathrm{mm})^{\mathrm{c}}\end{array}$ \\
\hline GPEPC68 & Roujol, Petit-Bourg & February 2003 & F148 & Leaf symptom & $2.0(0)$ \\
\hline GPEPC71 & Roujol, Petit-Bourg & February 2003 & FR90771 & Leaf symptom & $3.2(0.4)$ \\
\hline GPEPC73 & Roujol, Petit-Bourg & February 2003 & H63-1418 & Leaf symptom & $0.0(0)$ \\
\hline GPEPC75 & Roujol, Petit-Bourg & February 2003 & IAC58-480 & Leaf symptom & $3.0(0)$ \\
\hline GPEPC77 & Roujol, Petit-Bourg & February 2003 & LF610003 & Leaf symptom & $3.2(0.8)$ \\
\hline GPEPC79 & Roujol, Petit-Bourg & February 2003 & M377/56 & Leaf symptom & $0.0(0)$ \\
\hline GPEPC80 & Roujol, Petit-Bourg & February 2003 & PR1116 & Leaf symptom & $3.5(0)$ \\
\hline GPEPC81 & Roujol, Petit-Bourg & February 2003 & $\mathrm{ONO}$ & Leaf symptom & $1.3(0.2)$ \\
\hline GPEPC83 & St. Jean, Petit-Bourg & March 2003 & FR90714 & Leaf symptom & $\ldots$ \\
\hline GPEPC84 & St. Jean, Petit-Bourg & March 2003 & SP71-6168 & Leaf symptom & $3.2(0.2)$ \\
\hline GPEPC86 & Meynard, Petit-Bourg & March 2003 & В69566 & Leaf symptom & $2.0(0)$ \\
\hline GPEPC87 & Meynard, Petit-Bourg & March 2003 & B69566 & Leaf symptom & $2.7(0.2)$ \\
\hline GPEPC89 & G. Montagne, Lamentin & March 2003 & B69566 & Leaf symptom & $0.5(0)$ \\
\hline GPEPC90 & P. Canal, Port-Louis & March 2003 & B69566 & Leaf symptom & $1.7(0.2)$ \\
\hline GPEPC91 & P. Canal, Port-Louis & March 2003 & B69566 & Leaf symptom & $0.5(0)$ \\
\hline GPEPC92 & P. Canal, Port-Louis & March 2003 & B69566 & Leaf symptom & $1.5(1.0)$ \\
\hline GPEPC94 & St. Sauveur, Capesterre B. Eau & March 2003 & B69566 & Leaf symptom & $0.8(0.4)$ \\
\hline GPEPC101 & St. Sauveur, Capesterre B. Eau & March 2003 & B69566 & Leaf surface & $0.0(0)$ \\
\hline GPEPC103 & St. Sauveur, Capesterre B. Eau & March 2003 & B69566 & Leaf symptom & $2.0(0)$ \\
\hline GPEPC106 & St. Sauveur, Capesterre B. Eau & March 2003 & B69566 & Leaf symptom & $1.5(0.3)$ \\
\hline GPEPC109 & St. Sauveur, Capesterre B. Eau & March 2003 & B69566 & Leaf symptom & $2.3(0.2)$ \\
\hline GPEPC112 & St. Sauveur, Capesterre B. Eau & March 2003 & B69566 & Leaf symptom & $1.2(0.4)$ \\
\hline GPEPC117 & St. Sauveur, Capesterre B. Eau & March 2003 & B69566 & Leaf symptom & $\ldots$ \\
\hline GPEPC 120 & St. Sauveur, Capesterre B. Eau & March 2003 & B69566 & Leaf symptom & $\ldots$ \\
\hline GPEPC125 & St. Sauveur, Capesterre B. Eau & March 2003 & B69566 & Leaf symptom & $0.8(0.4)$ \\
\hline GPEPC126 & St. Sauveur, Capesterre B. Eau & March 2003 & B69566 & Leaf symptom & $0.0(0)$ \\
\hline GPEPC127 & St. Sauveur, Capesterre B. Eau & March 2003 & B69566 & Leaf symptom & $2.2(0.2)$ \\
\hline GPEPC128 & St. Sauveur, Capesterre B. Eau & March 2003 & B69566 & Leaf symptom & $2.8(0.2)$ \\
\hline GPEPC131 & Christophe Ouest, Goyave & March 2003 & B69566 & Leaf symptom & $3.3(0.2)$ \\
\hline GPEPC133 & Christophe Ouest, Goyave & March 2003 & B69566 & Leaf symptom & $3.5(0.7)$ \\
\hline GPEPC135 & St. Louis, Marie-Galante & March 2003 & B69566 & Stalk & $1.0(0.7)$ \\
\hline GPEPC137 & St. Louis, Marie-Galante & March 2003 & B69566 & Stalk & $\ldots$ \\
\hline GPEPC139 & St. Louis, Marie-Galante & March 2003 & B69566 & Leaf symptom & $2.7(0.2)$ \\
\hline GPEPC140 & St. Louis, Marie-Galante & March 2003 & B69566 & Stalk & $0.5(0)$ \\
\hline GPEPC141 & St. Louis, Marie-Galante & March 2003 & B69566 & Leaf symptom & $0.5(0)$ \\
\hline GPEPC142 & Cluny, Sainte-Rose & March 2003 & B69566 & Leaf symptom & $4.3(0.2)$ \\
\hline GPEPC143 & Cluny, Sainte-Rose & March 2003 & B69566 & Leaf symptom & $4.3(0.2)$ \\
\hline GPEPC145 & Cluny, Sainte-Rose & March 2003 & B69566 & Leaf symptom & $0.0(0)$ \\
\hline GPEPC146 & Cluny, Sainte-Rose & March 2003 & B69566 & Leaf symptom & $2.3(0.2)$ \\
\hline GPEPC148 & Roujol, Petit-Bourg & March 2003 & NCo376 & Stalk & $0.8(0.4)$ \\
\hline
\end{tabular}


Extent of stalk colonization (ESC) was expressed as ESC = $100\left(\left[1 \times N_{1}+2 \times N_{2}+3 \times N_{3}+4 \times N_{4}\right] / 4 \times N_{T}\right)$, where $N_{i}=$ number of internodes with score $i$ and $N_{T}=$ total number of internodes.

RFLP analysis of total genomic DNA. PFGE was used for RFLP analysis of the 19 strains of $X$. albilineans selected herein (Table 2), after restriction of total genomic DNA with the rare cutting enzyme SpeI, as described by Davis et al. (17). Strain Xa23R1 from Florida (41) was used as the reference strain.

RFLP analysis of albicidin biosynthesis genes. Two DNA plasmids (pALB571 and pBKS/K7), which cover all three genomic regions involved in albicidin biosynthesis, were used as probes for RFLP analysis of the 19 strains of $X$. albilineans selected herein (Table 2), as described by Champoiseau et al. (12). Strain Xa23R1 from Florida was used as the reference strain.

AFLP analysis. Template DNA, enzymes for restriction, specific adaptors for ligation, and primers for selective amplification were designed based on a preliminary study by Pilet et al. (31). In all, 80 to $100 \mathrm{ng}$ of DNA were digested for $2 \mathrm{~h}$ at $37^{\circ} \mathrm{C}$ (followed by $10 \mathrm{~min}$ at $65^{\circ} \mathrm{C}$ ) in a $25-\mu \mathrm{l}$ reaction mixture with 6/6.4 units of $M s p I / S a c I$ enzyme combination (Promega Corp., Madison, WI) and ligated with specific adaptors. Double-stranded DNA adaptors were prepared by $15 \mathrm{~min}$ of denaturation at $75^{\circ} \mathrm{C}$ and overnight renaturation of the two oligonucleotides in a reaction mixture containing $1 \times$ enzyme buffer and $20 \mu \mathrm{M}$ of each oligonucleotide. MspI adaptor (5'-GACGATGAGTCCTGAA-3' and $3^{\prime}$-GCTACTCAGGACTTGC-5') and SacI adaptor (5'-CTCGTAGACTGCGTACAAGCT-3' and 3'-GCATCTGACGCATGT-5') were ligated into restricted DNA for $2.5 \mathrm{~h}$ at $14^{\circ} \mathrm{C}$ in $50 \mu \mathrm{l}$ of reaction mixture $(25 \mu \mathrm{l}$ of restricted DNA, $1 \times$ ligase buffer, 4.2 units of T4 DNA ligase [Promega Corp.], $2 \times$ bovine serum albumen, 50 pmol MspI adaptor, and 5 pmol SacI adaptor). The ligation solution was diluted 2.5 -fold in water and stored at $-20^{\circ} \mathrm{C}$ before selective amplification.

The following combinations of selective primers were used for AFLP analysis because they generated reliable and easily identifiable DNA fingerprints in preliminary experiments (data not shown): SacI + G (5'-TAGACTGCGTACAAGCTCG-3')/MspI + Y (5'-CGATGAGTCCTGAACGGY-3'), where Y = A, T, G, or CT. SacI selective primer was labeled with ${ }^{33} \mathrm{P}$-ATP using the T4 kinase according to the manufacturer's recommendations (Invitrogen, Carlsbad, CA) and used for amplification. The ligation solution $(5 \mu \mathrm{l})$ was amplified in a $20-\mu$ reaction mixture $(1 \times$ enzyme buffer, $2 \mathrm{mM} \mathrm{MgCl}_{2}, 0.3 \mathrm{mM}$ dNTP, $0.1 \mu \mathrm{M}{ }^{33} \mathrm{P}$-labeled SacI primer, and $1 \mu \mathrm{M} \mathrm{MspI} \mathrm{primer)} \mathrm{containing} 1$ unit of Taq DNA polymerase (Eurobio, Paris, France). PCR amplifications were performed in an automated thermal cycler with the initial cycle at $94^{\circ} \mathrm{C}$ for $30 \mathrm{~s}, 65^{\circ} \mathrm{C}$ for $30 \mathrm{~s}$, and $72^{\circ} \mathrm{C}$ for $60 \mathrm{~s}$, followed by 12 cycles with subsequent reduction of annealing temperature by $0.7^{\circ} \mathrm{C}$ per cycle, and 23 cycles at $94^{\circ} \mathrm{C}$ for $30 \mathrm{~s}, 56^{\circ} \mathrm{C}$ for $30 \mathrm{~s}$, and $72^{\circ} \mathrm{C}$ for $60 \mathrm{~s}$. After amplification, $20 \mu \mathrm{l}$ of sequencing dye (98\% formamide, $10 \mathrm{mM}$ EDTA, $0.025 \%$ xylene cyanol, and $0.025 \%$ bromophenol blue) was added to each reaction mixture, and the final solution was heated at $94^{\circ} \mathrm{C}$ for $3 \mathrm{~min}$ and kept warm at $70^{\circ} \mathrm{C}$ during loading of the electrophoresis gel. A 6- $\mu \mathrm{l}$ aliquot of each sample was separated on a $5 \%$ polyacrylamide denaturing gel containing $7.5 \mathrm{M}$ urea and $0.5 \times$ Tris-borate EDTA (TBE) running buffer (Qbiogene, Illkirch, France) at $55 \mathrm{~W}$ for 1.8 to $2.0 \mathrm{~h}$, in a 30 -by-40-cm sequencing apparatus. After electrophoresis, gels were covered with Saran Wrap, transferred to Whatman 3-mm chromatography paper, dried under vacuum at $80^{\circ} \mathrm{C}$ for $30 \mathrm{~min}$, and exposed to radiographic films for 12 to $24 \mathrm{~h}$. Duplicated AFLP fingerprints were obtained for each strain

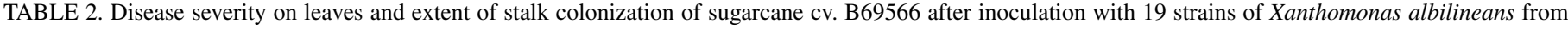
Guadeloupe $^{\mathrm{a}}$

\begin{tabular}{|c|c|c|c|c|c|}
\hline \multirow[b]{3}{*}{ Strain } & & \multicolumn{4}{|c|}{ Mean (square mean) } \\
\hline & & \multicolumn{2}{|c|}{ Disease severity $^{b}$} & \multicolumn{2}{|c|}{ Extent of stalk colonization $^{c}$} \\
\hline & & Trial A & Trial B & Trial A & Trial B \\
\hline GPEPC17 & & $0.0(0)$ & $0.0(0)$ & $0.0(0)$ & $12.2(14.5)$ \\
\hline GPEPC23 & & $0.0(0)$ & $1.3(2.5)$ & $3.8(6.0)$ & $7.5(7.6)$ \\
\hline GPEPC52 & & $28.0(33.6)$ & $52.7(27.8)$ & $34.1(27.3)$ & $63.3(26.2)$ \\
\hline GPEPC73 & & $52.0(25.6)$ & $78.8(6.9)$ & $81.3(9.4)$ & $93.4(7.6)$ \\
\hline GPEPC75 & & $16.0(21.6)$ & $26.3(25.3)$ & $51.0(20.8)$ & $60.8(23.7)$ \\
\hline GPEPC79 & & $26.0(31.2)$ & $40.0(22.5)$ & $30.5(17.8)$ & $67.2(19.4)$ \\
\hline GPEPC80 & & $8.0(12.8)$ & $14.7(17.6)$ & $4.0(6.4)$ & $48.0(21.2)$ \\
\hline GPEPC81 & & $0.0(0)$ & $2.5(4.4)$ & $32.6(28.9)$ & $16.6(15.6)$ \\
\hline GPEPC83 & & $0.0(0)$ & $2.5(4.4)$ & $54.5(18.6)$ & $42.8(25.9)$ \\
\hline GPEPC84 & & $4.0(6.4)$ & $0.0(0)$ & $3.3(5.3)$ & $12.2(10.5)$ \\
\hline GPEPC86 & & $0.0(0)$ & $0.0(0)$ & $0.0(0)$ & $18.2(16.6)$ \\
\hline GPEPC87 & & $28.0(17.6)$ & $36.9(26.5)$ & $61.3(29.1)$ & $74.2(16.7)$ \\
\hline GPEPC91 & & $0.0(0)$ & $28.1(26.6)$ & $23.3(25.7)$ & $56.7(27.6)$ \\
\hline GPEPC101 & & $0.0(0)$ & $0.0(0)$ & $5.0(8.0)$ & $4.9(5.1)$ \\
\hline GPEPC106 & & $0.0(0)$ & $0.0(0)$ & $6.7(10.7)$ & $16.8(11.8)$ \\
\hline GPEPC 125 & & $0.0(0)$ & $3.1(5.9)$ & $3.0(4.8)$ & $10.2(10.1)$ \\
\hline GPEPC142 & & $8.0(12.8)$ & $18.8(21.1)$ & 39.7 (27.6) & $42.3(16.5)$ \\
\hline GPEPC143 & & $50.0(24.0)$ & $44.4(16.3)$ & $63.4(5.7)$ & $73.2(8.7)$ \\
\hline GPEPC 145 & & $20.0(8.0)$ & $43.8(15.8)$ & $55.8(10.3)$ & $69.1(11.4)$ \\
\hline \multicolumn{6}{|c|}{ Variance analysis } \\
\hline \multicolumn{6}{|c|}{ Source } \\
\hline Strain & DF & 18 & 18 & 18 & 18 \\
\hline Strain & $(P>F)$ & $<0.0001$ & $<0.0001$ & $<0.0001$ & $<0.0001$ \\
\hline Bloc & $\mathrm{DF}$ & 4 & 3 & 4 & 3 \\
\hline Bloc & $P>F$ & 0.137 & 0.383 & 0.287 & 0.566 \\
\hline Strain $\times$ bloc & $\mathrm{DF}$ & $\ldots$ & 54 & $\ldots$ & 54 \\
\hline Strain $\times$ bloc & $P>F$ & $\ldots$ & 0.544 & $\ldots$ & 0.246 \\
\hline Error DF & & 72 & 225 & 71 & 228 \\
\hline
\end{tabular}

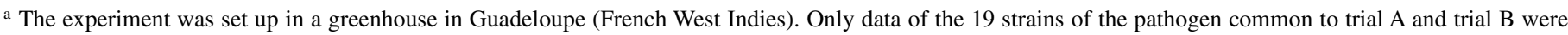
used for statistical analysis.

${ }^{\mathrm{b}}$ Disease severity on a scale of 0 to 100 was determined 12 weeks after plant inoculation in both trials.

${ }^{c}$ Extent of stalk colonization on a scale of 0 to 100 was determined 17 and 16 weeks after plant inoculation in trial A and trial B, respectively.
} 
and each selective primer combination with two different DNA preparations. Only reproducible and strong DNA bands observed in both duplications were scored for DNA analysis.

Binary scores were attributed based on the presence or absence ( 1 or 0 , respectively) of DNA bands. Binary matrices were used to calculate similarity between paired haplotypes with Jaccard's similarity index (45). Unweighted pair-group method with arithmetic means (UPGMA) dendrograms showing cluster analysis of the distance matrix were constructed with the DARwin program (version 4.0; CIRAD-FLHOR, Montpellier, France).

PCR identification of pathogenicity-related genes. Total genomic DNA of nine strains of $X$. albilineans differing in pathogenicity in Guadeloupe (GPEPC17, GPEPC73, GPEPC75, GPEPC84, GPEPC86, GPEPC87, GPEPC101, GPEPC142, and GPEPC143) and $X$. albilineans strain Xa23R1 from Florida was used as template DNA to amplify partial pathogenicity-related genes by PCR. Eighty oligonucleotide primers were designed to amplify 40 gene fragments (Table 3 ). Genomic DNA (1 $\mu$ l) was used as template in a 50- $\mu$ l reaction mixture (1× enzyme buffer, $2 \mathrm{mM} \mathrm{MgCl}_{2}, 0.2 \mathrm{mM}$ dNTP mix, and $0.3 \mu \mathrm{M}$ of each primer) containing 2.5 units of Taq DNA polymerase (Eurobio). PCR amplification was performed in an automated thermocycler with the following program: $95^{\circ} \mathrm{C}$ for $5 \mathrm{~min}$, and 30 cycles that included $94^{\circ} \mathrm{C}$ for $1 \mathrm{~min}$, annealing temperature for $1 \mathrm{~min}, 72^{\circ} \mathrm{C}$ for $1 \mathrm{~min}$, and a final extension at $72^{\circ} \mathrm{C}$ for $7 \mathrm{~min}$. PCR products were separated by electrophoresis in a $1 \%$ agarose gel in $0.5 \times$ TBE buffer (Qbiogene), stained with ethidium bromide, and visualized by UV transillumination. ProMega-Marker Lambda Ladder $1 \mathrm{~kb}$ (Promega Corp.) was used as molecular weight marker.

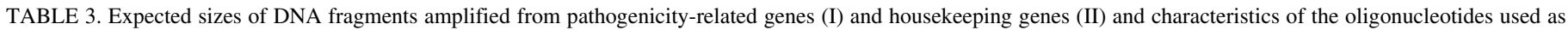
primers for polymerase chain reaction (PCR) amplification

\begin{tabular}{|c|c|c|c|c|c|c|}
\hline \multicolumn{2}{|c|}{ DNA fragment ${ }^{\mathrm{a}}$} & \multicolumn{3}{|c|}{ Primer sequences $\left(5^{\prime}>3^{\prime}\right)^{\mathrm{b}}$} & \multirow[b]{2}{*}{ No. or reference ${ }^{c}$} & \multirow[b]{2}{*}{ Protein function ${ }^{\mathrm{d}}$} \\
\hline Name & Size (bp) & Forward & Reverse & From & & \\
\hline \multicolumn{7}{|l|}{ I. } \\
\hline adh & 731 & GAACTGTTTCGGTAGGTGATG & CTGATAACCCACACCTGCAC & Xf9a5c, Xftem & AAF84783 & Surface protein \\
\hline cbas & 437 & GATATCGGCCATTCCGGCT & CTCTGATTGCACCARTTGCC & Xac, Xcc, Xoo & AAM42804 & 1,4- $\beta$-Cellobiosidase \\
\hline clas & 353 & CGGCTCSGGCTAYTCKGGC & GCACCTGGATCGCSGCCCA & Xac, Xoo & AAM42805 & Cellulase \\
\hline gumB & 596 & CTGGGCGCTTGCAGCACC & TCCAGCATGGTGCGCAACC & Xac, Xcc, Xoo & AAA 86370 & Gum B \\
\hline gumD & 1447 & GCTTTTGGCAGACTTGAGTAGC & ACGCGGTCTTCTGTCCGAGC & Xac, Xcc, Xoo & AAA86372 & Gum D \\
\hline gumE & 616 & ACTGGCAGATCGACCCCAAG & CCCATCGTGGTGTCCTGGT & Xac, Xcc, Xoo & AAA86373 & Gum E \\
\hline gumF & 736 & GGCTGGCTGCCGGTTATG & GCCAAGGCCGCAACACC & Xac, Xcc, Xoo & AAA86374 & Gum F \\
\hline gumH & 795 & CGTGTGTTCACCGATC & GGCAAGCCGCACGAA & Xac, Xcc, Xoo & AAA86376 & Gum H \\
\hline gumI & 615 & GCAGCTGACCGGCAC & GCATCGAACTCGCCTTC & Xac, Xcc, Xoo & AAA86377 & Gum I \\
\hline gumJ & 941 & GTGCAGTTCGGCGGC & GCCGTCTGGAAGATACC & Xac, Xcc, Xoo & AAA86378 & Gum J \\
\hline gumK & 596 & CGCGAGTTCGACCGCG & TCGGTGGTGTCGGACC & Xac, Xcc, Xoo & AAA86379 & Gum K \\
\hline gumL & 608 & TGTTCTGGTGGCAGCCC & GTAGTAGTCGTCGTACTTG & Xac, Xcc, Xoo & AAA86380 & Gum L \\
\hline gumP & 792 & TGCGAACGCATGGTGCGC & CCACTCCGGTTGATAACGG & Xac, Xcc, Xoo & AAM41716 & Gum P \\
\hline hemag 1 & 727 & CGCGCCCAACTCATCATTGC & GGTTGTCCAGGTGTTGGGTC & Xf9a5c, Xftem & AAO29937 & HLS protein \\
\hline hemag2 & 734 & CACCCACACCGACCTCAGC & CGGTGGTGGTGCCGAGGC & Xf9a5c, Xftem & AAO29937 & HLS protein \\
\hline pect & 435 & ACTATGTCGAAGGCACTTAC & GCGAGGTGCCGTTGACG & Xcc, Xoo & AAM41544 & Pectinesterase \\
\hline hrp1 & 840 & AGGCCCTGGAAGGTGCCCTGGA & ATCGCACTGCGTACCGCGCGCGA & $\mathrm{Xcv}$ & Leite et al. (27) & $\mathrm{HrcL}$ and $\mathrm{HrcN}$ proteins \\
\hline hrp2 & 355 & AATACGCTGGAACTGCTG & GGCACTATGCAATGACTG & $\mathrm{Xcv}$ & Leite et al. (27) & $\mathrm{HrcN}$ and $\mathrm{HrpB} 7$ proteins \\
\hline pgl & 662 & GGCCTGGGCACCTGCGGC & CGCACGGCGATATGGCGCAT & Xac, Xcc, Xoo & AAM41545 & Polygalacturonase \\
\hline pilB & 684 & CGCCGGTGGTGAAGTTCGTC & CCGCCTTGATCGCAATCTCG & Xac, Xcc, Xoo & AAP43029 & Pilus biogenesis protein $\mathrm{B}$ \\
\hline pilD & 603 & TCGACCAGCATCCCGGTCTC & CTTCCTTGCCGGTGAGCTGC & Xac, Xcc, Xoo & AAP43033 & $\begin{array}{l}\text { Type IV pre-pilin leader } \\
\text { peptidase }\end{array}$ \\
\hline pilG & 331 & GCGGGTGGGGAACTCGCAG & GCTTGGTCAGATATTGCTCGG & Xac, Xcc, Xoo & AAM42197 & Pilus \\
\hline pilH & 308 & TTGATCGAGGACTCGCCCAC & TCGCGCGGCGGCTTGACG & Xac, Xcc, Xoo & AAM42196 & PilH \\
\hline pilJ & 598 & ATCAGCTCGCTCGGTGAGGG & GGGTCGCACTGGAGGTGCG & Xac, Xcc, Xoo & AAM42194 & Pilus biogenesis protein \\
\hline rpfA1 & 947 & ATGAGCGATTCCTTTTCCAC & GGGAAGATGCCGCAGGTG & Xac, Xcc, Xoo & AAM41149 & Aconitase \\
\hline $\operatorname{rpfA} 2$ & 1140 & CTGCATCGGCAACTCCGGC & CCGTGCTTGAAGTACTCCAC & Xac, Xcc, Xoo & AAM41149 & Aconitase \\
\hline $\mathrm{rpfB}$ & 1129 & ACAGCTTCGGCAAGACC & CCCTTCATCACCTGCGG & Xac, Xcc, Xoo & AAM41147 & RpfB protein \\
\hline $\mathrm{rpfC}$ & 698 & GGCAATGCGGTCAAGTTC & TCGGCGCTGAGCACCAC & Xac, Xcc, Xoo & AAM41145 & RpfC protein \\
\hline rpfG & 1041 & GATTGAACATCGTCATTGTC & CCGATGCGGTGGAGAAC & Xac, Xcc, Xoo & AAM41143 & $\mathrm{RR}$ protein \\
\hline xad & 914 & ACCGAAGGCACCGATGCG & TCACCCCACGCCACACTG & Xac, Xcc & AAM39974 & Outer membrane protein \\
\hline xpsE & 570 & CGTGCTGGTGGAAGGCGAAAG & AGCGCGGACTGGATCGCGAT & Xac, Xcc, Xoo & AAM39976 & GSP protein $\mathrm{E}$ \\
\hline $\mathrm{xpsF}$ & 675 & CATCAACATGGTGCGCGCGG & GTGTCGGCGGTCTTGAGCAG & Xac, Xcc, Xoo & AAM39977 & GSP protein $F$ \\
\hline xpsG & 291 & CAGGCCGGCATGAGCTTGCT & GTATTCGATGGYGTGGCCCCA & Xac, Xcc, Xoo & AAM39978 & GSP protein $\mathrm{G}$ \\
\hline xpsI & 369 & TGATCGAAGTGATCGTCGCCT & TGGCSGYCACCAGCCGCAA & Xac, Xcc, Xoo & AAM39980 & GSP protein I \\
\hline $\mathrm{xsaA}$ & 631 & CTGGCGCGCACCGCCATTT & CGTGTTCGTCGAGGATGACG & Xаc, Xcc, Xoo & AAM43343 & Xylosidase/arabinosidase \\
\hline $\mathrm{xsaB}$ & 772 & TGTCGGTCGGCTCGGATTTTC & TAGCTGCTGCTCCACTCGGT & Xac, Xcc & AAM43196 & $\beta$-Xylosidase \\
\hline xylA1 & 615 & TCCCCGGCATCGGCAAGATC & CCATGTTGTCCTGCTCGCGC & Xac, Xcc, Xoo & AAM41049 & Xylose isomerase \\
\hline xylA2 & 482 & TGAAGCGCGAGCAGGACAACA & CGCGTCCATGCCGCCGATG & Xac, Xcc, Xoo & AAM41049 & Xylose isomerase \\
\hline xynA & 486 & ACCAACTGGGTGCAGCGCGT & CTTGTCGCGCTTGCGCCAG & Xac, Xcc & AAM43336 & Endo-1,4- $\beta$-xylanase A \\
\hline xynB & 294 & TGGGGCAACCAGCAGCCGG & GGTGATGCTGTAGTCGTTGATC & Xac, Xcc, Xoo & AAM43339 & Xylanase \\
\hline \multicolumn{7}{|l|}{ II. } \\
\hline efp & 491 & TCATCACCGAGACCGAAT & TCCTGGTTGACGAACAG & Xac, Xcc & $\begin{array}{l}\text { S. Boudon (personal } \\
\text { communication) }\end{array}$ & Elongation factor $\mathrm{P}$ \\
\hline ihfA (syn. gumA) & 289 & TGACGAAAGCGGAGATGGCCG & TGCCCGGATCCAGCATAAGCC & Xac, Xcc, Xoo & AAA86369 & Integration host factor A \\
\hline
\end{tabular}

a DNA fragments correspond to partial genes.

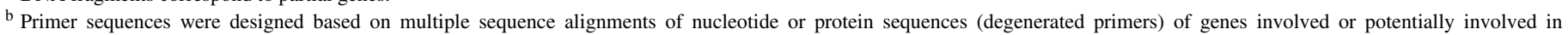
pathogenicity of the following phytopathogenic bacteria: Xanthomonas axonopodis pv. citri strain 306 (Xac), X. campestris pv. campestris strain ATCC 33913 (Xcc), X. campestris pv. vesicatoria (Xcv) (27), X. oryzae pv. oryzae strain KACC10331 (Xoo), or Xylella fastidiosa strain 9a5c (Xf9a5c) and strain Temecula1 (Xftem).

${ }^{\mathrm{c}}$ GenBank accession number (No.) refers to X. campestris pv. campestris strain ATCC 33913 and Xylella fastidiosa strains 9a5c or Temecula1.

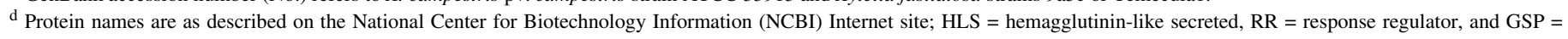
general secretion pathway. 
Total genomic DNA of $X$. campestris pv. campestris strain CFBP 5251, X. campestris pv. vesicatoria strain 91-118, or Xylella fastidiosa strain Temecula1 was used systematically as template DNA for a positive or negative control in all PCR amplification series.

Nucleotide sequence analysis of housekeeping genes. Total genomic DNA of nine strains of Xanthomonas albilineans differing in pathogenicity in Guadeloupe and X. albilineans strain Xa23R1 was used as template DNA to amplify, by PCR, partial housekeeping genes $e f p$ and ihfA. Oligonucleotides used as primers for PCR amplifications are listed in Table 3 and PCR amplifications were performed as described above.

Total genomic DNA of $X$. campestris pv. campestris strain CFBP 5251 and $X$. arboricola pv. pruni strain CFBP 6653 was used as template DNA for a positive control in all PCR amplifications series.

Phylogenetic analysis. In all, $30 \mu \mathrm{l}$ of amplicons obtained after PCR amplification of housekeeping genes efp and ihfA and pathogenicity-related genes pilB, rpfA, and $x p s E$ were sequenced by Genome Express (Meylan, France) using the same primers as used for PCR amplifications. Sequences were aligned and analyzed with DNAMAN Sequence Analysis Software (Lynnon BioSoft, Vaudreuil, Canada). The $5^{\prime}$ and $3^{\prime}$ end sequences of pilB, rpfA1, and xpsE PCR fragments were not obtained for all bacterial strains; therefore, the phylogenetic analyses were performed with the largest sequences common to all strains $(644,859$, and $539 \mathrm{bp}$, respectively). Complete PCR sequences of efp and ihfA PCR fragments were obtained for all bacterial strains and phylogenetic analyses were performed after removal of the primer sequences, leaving 455 and 245 bp, respectively. Jukes-Cantor's model was used to correct distances for multiple substitutions and phylogenetic trees were constructed with the neighbor-joining method (25). Robustness of nodes of the phylogenetic trees was assessed from 1,000 bootstrap resamplings.

Production of diffusible signal molecules. Biosensors Agrobacterium tumefaciens NT1 (pZLR4) (11) and X. campestris pv. campestris B24-B6 (32) and respective control strains were used to detect potential production of different diffusible molecules, $\mathrm{N}$ acylhomoserine lactones (AHLs), and PigB diffusible factor (DF) by $X$. albilineans strains. Biosensors were obtained from and were used as described by the respective authors $(11,32)$.

Statistical analysis. Values of DS and ESC each were compared with the General Linear Models procedure of SAS software (version 8.2; SAS Institute Inc., Cary, NC). Cluster analysis based on Euclidean distance was conducted by the UPGMA procedure $(45,51)$. Similarity calculations, cluster analyses, and dendrogram constructions were performed with DARwin program version 4.0 (CIRAD-FLHOR).

\section{RESULTS}

Characteristics of the collection of $X$. albilineans strains used in this study. The 75 strains of $X$. albilineans were sampled from 45 sugarcane cultivars and different geographic locations in Guadeloupe. All strains belonged to serovar I as determined by Rott et al. (39), and albicidin production varied among strains of the pathogen (Table 1).

Variation in pathogenicity of $X$. albilineans strains in Guadeloupe. In trial A, 12 weeks after inoculating plants with the 75 strains, DS varied between 0 (46 strains) and 52 (strain GPEPC73) on a scale of 0 to 100. At the end of the experiment, 17 weeks after plant inoculation, ESC varied between 0 (seven strains) and 81.3 (strain GPEPC73), also on a scale of 0 to 100. Nineteen strains representative of this variability were selected arbitrarily for subsequent testing in a second pathogenicity trial (trial B), with more plants inoculated per strain, and statistical analysis of data was performed with these strains in both trials (Table 2).
In trial A, 11 of 19 strains produced symptoms of the disease on noninoculated leaves. No disease symptoms were scored for eight strains at any time on any of the five inoculated plants (data not shown). Twelve weeks after inoculation, DS varied greatly between strains of the pathogen $(P<0.0001)$ and ranged from 0 to 52 (Table 2). Similarly, 17 weeks after plant inoculation, ESC was significantly different between strains $(P<0.0001)$ (Table 2$)$. Four groups of colonization were identified by cluster analysis based on ESC values (Fig. 1): a first group (SCG1) contained nonaggressive or weakly aggressive strains for which ESC varied from 0 (GPEPC17 and GPEPC86) to 6.7 (GPEPC106). A second group (SCG2) consisted of moderately aggressive strains for which ESC ranged from 23.3 (GPEPC91) to 39.7 (GPEPC142). A third group (SCG3) included highly aggressive strains, with ESC values varying from 51 (GPEPC75) to 63.4 (GPEPC143). The fourth group (SCG4) contained the most aggressive strain, with an ESC value of 81.3 (GPEPC73).

In trial B, 14 of 19 strains of the pathogen produced symptoms of the disease on noninoculated leaves. Five strains did not produce disease symptoms at any time on any of the 16 inoculated plants (data not shown). Twelve weeks after inoculation, DS varied significantly between strains of the pathogen $(P<0.0001)$ and ranged from 0 to 78.0 (Table 2).

Sixteen weeks after plant inoculation, stalk colonization varied greatly between strains of the pathogen (Table 2). As in trial A, four groups were identified by cluster analysis based on ESC values (Fig. 1). A first group (SCG1) included weakly aggressive strains with ESC values ranging from 5 (GPEPC101) to 18 (GPEPC86). A second group (SCG2) contained moderately aggressive strains for which ESC ranged from 42 (GPEPC142) to 48 (GPEPC80). A third group (SCG3) included highly aggressive strains, for which ESC values varied from 57 (GPEPC91) to 74 (GPEPC87). A fourth group consisted of the most aggressive strain, with an ESC value of 93 (GPEPC73).

Correlation of DS values $(R=0.91)$ and ESC values $(R=0.85)$ obtained for the 19 strains in trials $\mathrm{A}$ and $\mathrm{B}$ was high and indicated very good reliability of these results. Additionally, the 19 strains of $X$. albilineans were distributed in four DS groups that were similar to the four stalk colonization groups (data not shown).

Genetic variation in $X$. albilineans from Guadeloupe analyzed by PFGE and Southern hybridization with albicidin biosynthesis genes. Banding patterns were observed for all 20 strains of $X$. albilineans (19 strains from Guadeloupe tested in pathogenicity trials $\mathrm{A}$ and $\mathrm{B}$ and strain Xa23R1 from Florida) when total genomic DNA was separated by PFGE after enzymatic restriction with SpeI. A single banding pattern, corresponding to haplotype B-02 described by Davis et al. (17), was obtained for all strains from Guadeloupe. The banding pattern of strain Xa23R1 was different and corresponded to haplotype A-01, described by Davis et al. (17). Banding patterns also were observed for all strains when total genomic DNA was hybridized with probes pALB571 and pBKS/K7 harboring the albicidin biosynthesis genes, following enzymatic restriction with HincII. A single pattern was observed for the 19 strains from Guadeloupe which differed from the pattern of strain Xa23R1: 15 DNA bands (ranging from 0.67 to $>5.0 \mathrm{~kb}$ ) and 7 DNA bands (ranging from 0.57 to $>6.5 \mathrm{~kb}$ ) were obtained with probes pALB571 and $\mathrm{pBKS} / \mathrm{K} 7$, respectively. These banding patterns corresponded to combined haplotype HB2 as described by Champoiseau et al. (12). Banding patterns of Xa23R1 were different and corresponded to combined haplotype HA1.

Genetic variation in $X$. albilineans from Guadeloupe analyzed by AFLP. Nine strains of $X$. albilineans (GPEPC17, GPEPC73, GPEPC75, GPEPC84, GPEPC86, GPEPC87, GPEPC101, GPEPC142, and GPEPC143) from Guadeloupe that were distributed in the same colonization groups in trials A and B, representative of the variability of pathogenicity revealed in this 
study, were used to study genetic variation of the pathogen by AFLP (Tables 1 and 2). Banding patterns were observed for all strains and these patterns varied according to the strain of $X$. albilineans following PCR amplification of total genomic DNA with all four selective primer combinations (data not shown). The polymorphic band positions obtained with the four primer combinations were scored and combined for each strain, and six combined haplotypes were defined. These combined haplotypes were distributed into two major genetic groups (AFLP A and AFLP B)
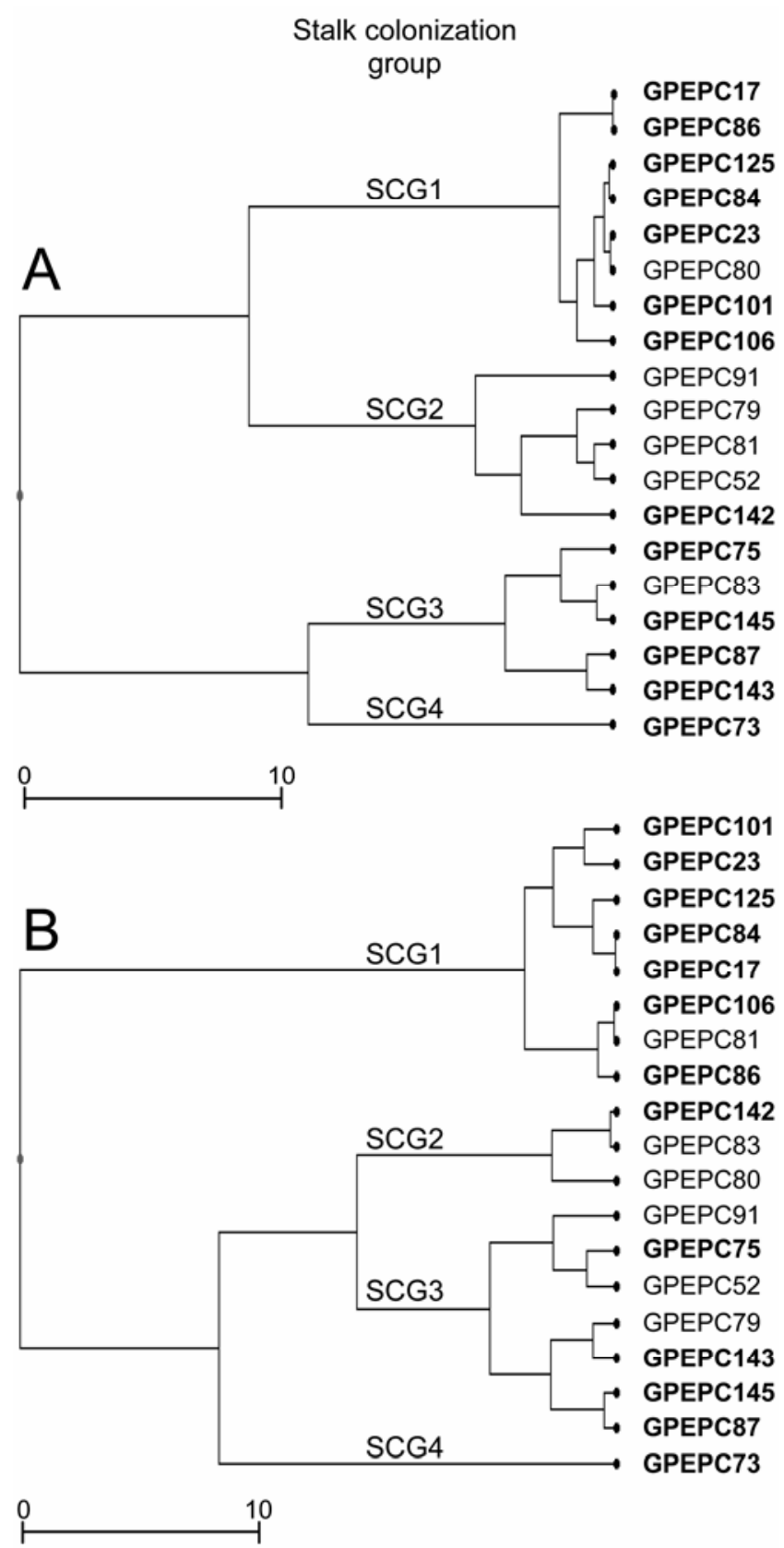

Fig. 1. Unweighted pair group method with arithmetic means dendrograms showing similarity among 19 strains of Xanthomonas albilineans based on extent of sugarcane stalk colonization (ESC) 17 and 16 weeks after inoculation of sugarcane cv. B69566 in A, trial A and B, trial B, respectively. ESC was calculated with bacterial population densities that were determined in every other internode and in all internodes above the location of the three shortened stalk internodes that showed reduced growth after mechanical plant inoculation (cut leaves above the growing point) $\left(\mathrm{SL}_{0}\right)$ in $\mathbf{A}$, trial $\mathrm{A}$ and $\mathbf{B}$, trial $\mathbf{B}$, respectively. SCG1 through SCG4 refer to different groups of increasing ESC that were identified in this study. Strain names in bold indicate strains of $X$. albilineans that were distributed in the same groups of stalk colonization in trials A and B. Scale bar represents Euclidean distance between strains based on ESC values. by cluster analysis (Fig. 2). In each of these two groups, strains of $X$. albilineans originated from different locations in Guadeloupe and belonged to different groups of stalk colonization (Fig. 1). Similarly, strains belonging to a single haplotype (GA2 or GB3) differed in pathogenicity.

PCR amplification of pathogenicity-related genes from $X$. albilineans. Single DNA bands of expected sizes were obtained after PCR amplification of total genomic DNA from $X$. campestris pv. campestris, $X$. campestris pv. vesicatoria, or $X$. fastidiosa strains, used as positive controls, with 40 primer sets (Table 3). Only three DNA fragments (pilB, rpfA1, and xpsE) could be amplified with these primers from total genomic DNA of nine strains of $X$. albilineans from Guadeloupe differing in pathogenicity, and strain Xa23R1 from Florida. No variation was observed in the nucleotide sequence of these DNA fragments among the strains from Guadeloupe; however, eight single synonymous nucleotide mutations (SNM), five SNM and one single nonsynonymous mutation, and four SNM were found between the nine Guadeloupean strains and Floridian strain Xa23R1 for DNA fragments pilB, rpfA1, and xpsE, respectively.

Phylogenetic relationship between $X$. albilineans and other pathogenic and nonpathogenic bacteria. DNA fragments efp and ihfA were amplified from housekeeping genes efp and ihfA (Table 3). No variation was observed in the nucleotide sequence of these DNA fragments among the nine strains from Guadeloupe and strain Xa23R1 from Florida. All these strains were grouped into a single phylogenetic cluster by phylogenetic analysis with sequences of housekeeping genes efp and $i h f A$, and pathogenicityrelated genes pilB, rpfA, and $x p s E$ (Fig. 3). Percent identity of the $X$. albilineans strains varied between 85.6 and $90.0 \%$ with the cluster containing all the other xanthomonads, and between 74.4 and $79.3 \%$ with the two strains of $X$. fastidiosa (Table 4).

Production of diffusible signals. No AHL activity was detected in the supernatant of 5-day-old liquid cultures of the nine strains of $X$. albilineans from Guadeloupe differing in patho-

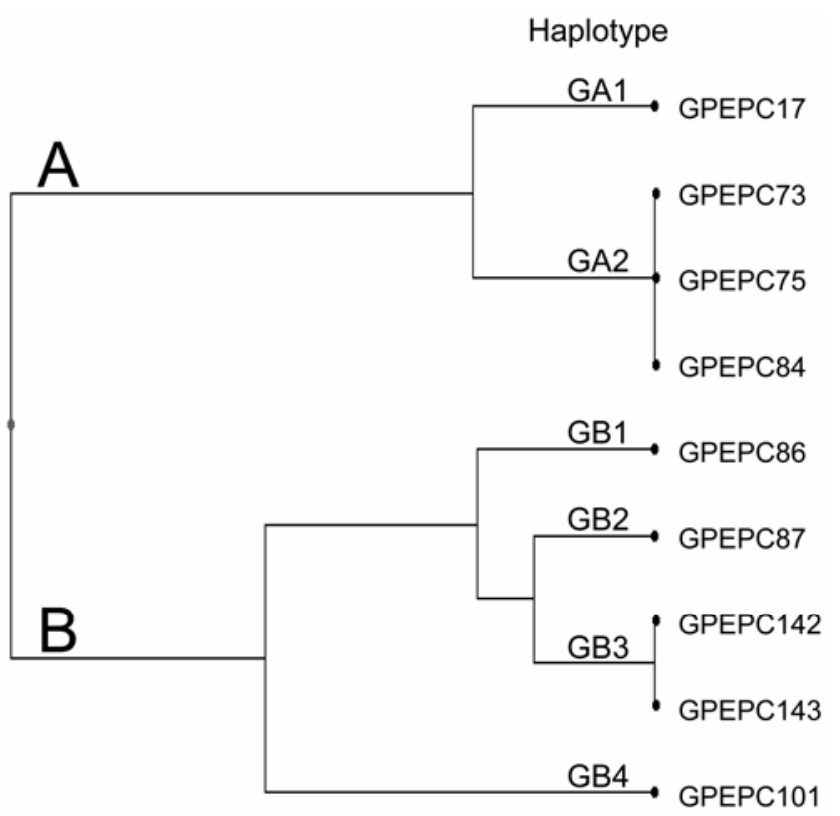

Fig. 2. Genetic relatedness of nine strains of Xanthomonas albilineans from Guadeloupe based on amplified fragment length polymorphism (AFLP). After enzymatic restriction with $S a c \mathrm{I}$ and $M s p \mathrm{I}$, total genomic DNA was ligated with specific adapters and amplified by polymerase chain reaction with the selective primer combinations $S a c \mathrm{I}+\mathrm{G} / M s p \mathrm{I}+\mathrm{A}, S a c \mathrm{I}+\mathrm{G} / M s p \mathrm{I}+\mathrm{T}, S a c \mathrm{I}+$ $\mathrm{G} / M s p \mathrm{I}+\mathrm{G}$, and $S a c \mathrm{I}+\mathrm{G} / M s p \mathrm{I}+\mathrm{CT}$. Banding patterns obtained with the four primer combinations were combined in six linearly combined haplotypes (GA1, GA2, and GB1 to GB4). Combined haplotypes were used for hierarchical cluster analysis by the unweighted pair group method with arithmetic means, and two AFLP groups (A and $\mathbf{B})$ were distinguished. 
genicity or of strain Xa23R1 from Florida. No DF was detected in cultures of the same $10 \mathrm{X}$. albilineans strains 9 days after inoculation of agar plates with biosensor B24-B6. However, AHLs and DF were detected with the respective A. tumefaciens- and $X$. campestris pv. campestris-positive controls (data not shown).

Relationship between variation in pathogenicity and genetic or physiological variation of nine strains of $X$. albilineans from Guadeloupe. ESC, DS, genetic variability of the whole genome (by RFLP and AFLP), genetic variability of albicidin biosynthesis genes, and nucleotide sequence of two housekeeping genes and three pathogenicity-related genes were compared for nine strains of $X$. albilineans from Guadeloupe (Table 5). High variation in pathogenicity and four groups of colonization (stalk colonization groups SCG1 to SCG4) were identified. All strains shared the same haplotypes (B-02 and HB2) previously identified by RFLP on the whole genome (17) and with albicidin biosynthesis genes (12), respectively, thus confirming genetic homogeneity of $X$. albilineans strains in Guadeloupe. In contrast, small variation and two genetic groups (AFLP-A [combined haplotypes GA1 and GA2] and AFLP-B [combined haplotypes GB1 to GB4]) were identified by AFLP. However, no relationship be- tween this variation and variation in stalk colonization groups was found. Comparison of nucleotide sequence of two housekeeping genes (efp and $i h f A$ ) and three partial pathogenicity-related genes ( $p i l B, r p f A$, and xpsE) revealed no differences among the nine strains from Guadeloupe, but phylogenetic studies confirmed that $X$. albilineans belongs to the genus Xanthomonas.

\section{DISCUSSION}

In this study, we explored genetic and physiological variability of strains of $X$. albilineans differing in pathogenicity, aiming to identify specific markers associated with different pathotypes of this pathogen. High variation in pathogenicity of 75 strains of $X$. albilineans from Guadeloupe was shown, confirming the existence of different pathotypes of $X$. albilineans in this geographical location $(12,15)$. Surprisingly, most of the 75 strains produced no or only weak disease symptoms after inoculation of sugarcane cv. B69566, which is susceptible to leaf scald. Almost all these strains were sampled from necrotic symptoms on leaves (and different sugarcane cultivars) that were associated with aerial contamination by the pathogen, and that may occur without systemic
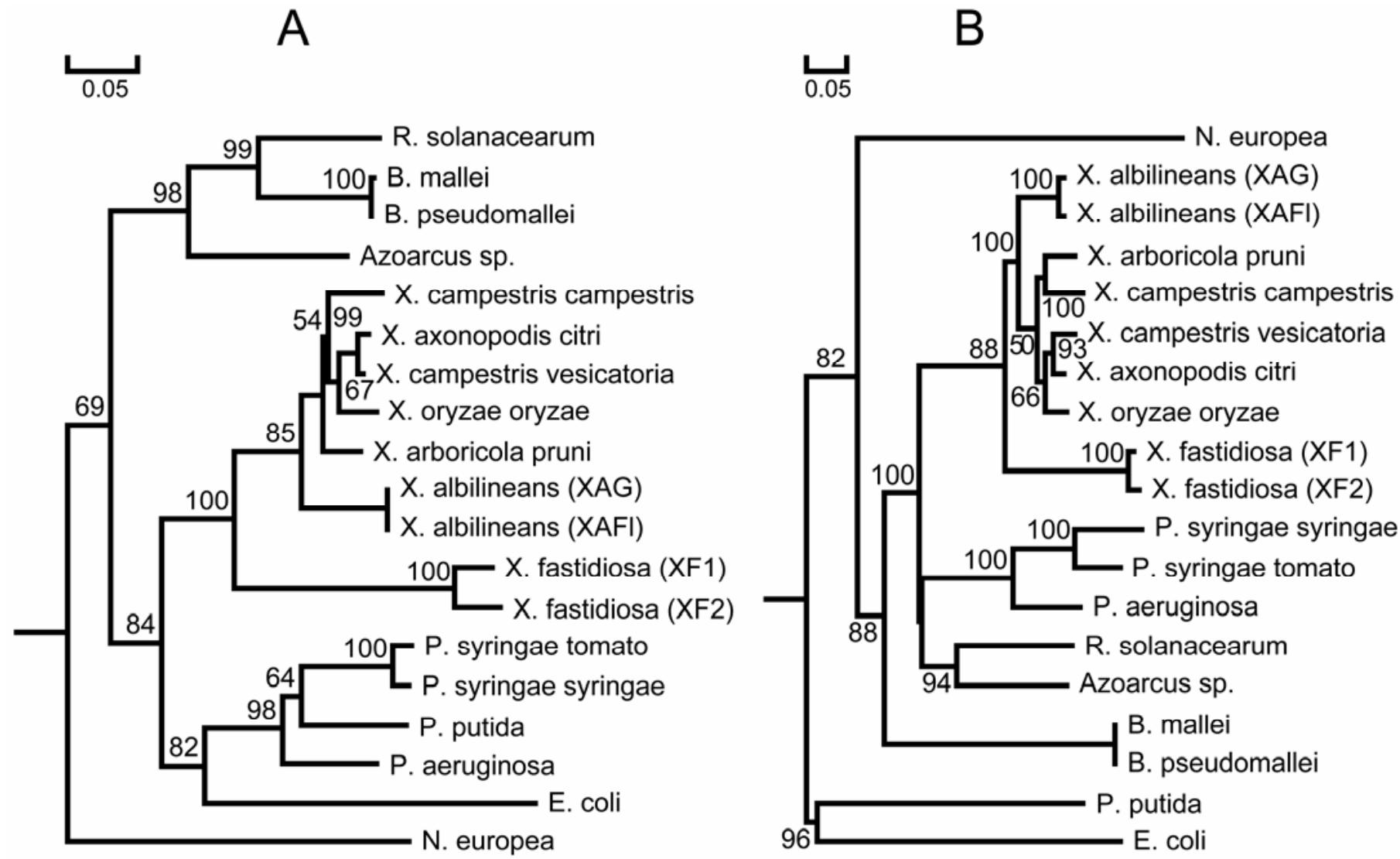

Fig. 3. Neighbor-joining tree of A, fragment ihfA (245-bp sequence of partial gene ihfA) and B, fragment pilB (644-bp sequence corresponding to partial gene pilB) nucleotide sequences of 10 strains of Xanthomonas albilineans and 17 other bacterial strains (including 1 nonpathogenic and 16 pathogenic strains). DNA fragments from $X$. albilineans strains from Guadeloupe (XAG = GPEPC17, GPEPC73, GPEPC75, GPEPC84, GPEPC86, GPEPC87, GPEPC101, GPEPC142, and GPEPC143), X. albilineans strain Xa23R1 (XAFI) from Florida, X. arboricola pv. pruni strain CFBP 6653, X. campestris pv. campestris strain ATCC 33913, and $X$. campestris pv. vesicatoria strain 91-118 were polymerase chain reaction amplified from total genomic DNA. Nucleotide sequence from other strains are from GenBank (accession no.; position): Azoarcus strain EbN1 (A, CR555306, 504922-504611; B, CR555306, 2574125-2572410), Burkholderia mallei strain ATCC 23344 (A, CP000010, 1133153-1133557; B, CP000010, 2635324-2636583), B. pseudomallei strain K96243 (A, BX571965, 2309571-2309224; B, BX571965, 3584982-3586241), Escherichia coli strain K-12 MG1655 (A, U00096, 1793576-1793277; B, U00096, 117099-115714), Nitrosomas europea ATCC 19718 (A, BX321859, 116386-116078; B, BX321861, 195575-193884), Pseudomonas aeruginosa strain PAO1 (A, AE004702, 1576-1274; B, AE004866, 9737-11437), P. putida strain KT2440 (A, AE016783, 101086-101388; B, AE016793, 185393-187066), P. syringae pv. syringae strain B728a (A, CP000075, 2522380-2522682; B, CP000075, 905203-903509), P. syringae pv. tomato strain DC3000 (A, AE016853, 2634012-2634314; B, AE016853, 1006981-1005287), Ralstonia solanacearum strain GMI1000 (A, AL646065, 87590-87904; B, AL646072, 26520-28247), Xanthomonas axonopodis pv. citri strain 306 (A, AE011899, 1068-769; B, AE011969, 10306-8570), Xyllela fastidiosa strain 9a5c (XF1) (A, AE003916, 5155-5454; B, AE004061, 3126-4859), X. fastidiosa strain Temecula1 (XF2) (A, AE012560, 134145-133856; B, AE012560, 153609-155342), and Xanthomonas oryzae pv. oryzae strain KACC10331 (A, AE013598, 3417819-3417520; B, AE013598, 1628312-1630099). Bootstrap values for 1,000 resamplings are shown as percentage. Similar phylogenetic trees were obtained with the nucleotide sequences from efp, rpfA, and $x p s E$ partial genes (data not shown). Scale bar units are in number of substitutions per nucleotide. 
colonization of the sugarcane stalk $(13,15)$. These data suggested that different mechanisms are involved in the capacity of the pathogen to colonize the leaf surface, with subsequent penetration into the host, and in the capacity to systemically colonize the sugarcane stalk, with subsequent systemic disease symptoms.

DS and ESC were characterized further for 19 of the 75 strains of the pathogen. Of the 19 strains, 13 were distributed among the same stalk colonization groups (groups SCG1 to SCG4) in two independent greenhouse experiments, indicating reliability of results (Fig. 1). Strains from a single geographic (field) location or isolated from the same sugarcane cultivar were distributed in different stalk colonization or DS groups. In contrast, strains from different geographic locations or sugarcane cultivars were distributed in the same stalk colonization or DS groups. Therefore, large differences in pathogenicity of $X$. albilineans can exist among strains of the pathogen, not only between different countries or geographical areas (12) but also within a single sugarcane field.

No genetic variation was identified among 19 pathogenic variants of $X$. albilineans, isolated in 2003 in Guadeloupe, by RFLP based on the whole genome or on albicidin biosynthesis genes. This result confirmed genetic homogeneity of recent populations of $X$. albilineans in Guadeloupe, although several genetic variants, serovars, and pathotypes have been reported in the past on this island $(12,15,17)$. Similar variation in pathogenicity or aggressiveness of genetically related strains was found by different DNA-based methods in several other plant-pathogenic bacteria $(24,29,30)$. In contrast, different strains of Ralstonia solanacearum were differentiated by AFLP, and especially strains that were not distinguished by an RFLP-based technique (33). Additionally, AFLP was used successfully to identify bacterial pathogenicity islands, genes involved in pathogenic fitness, and regulators of virulence of the bacterial pathogen $X$. axonopodis pv. manihotis after excision, amplification, cloning, and sequence homology analysis of polymorphic bands from AFLP gels (22). In this study, AFLP primer combinations $S a c \mathrm{I}+\mathrm{G} / M s p \mathrm{I}+$ $\mathrm{A}, S a c \mathrm{I}+\mathrm{G} / M s p \mathrm{I}+\mathrm{T}, S a c \mathrm{I}+\mathrm{G} / M s p \mathrm{I}+\mathrm{G}$, and $S a c \mathrm{I}+\mathrm{G} / M s p \mathrm{I}+$ $\mathrm{CT}$ also were efficient in identifying genetic variability within $X$. albilineans in Guadeloupe. Differences in gel resolution and

TABLE 4. Nucleotide sequence identity (\%) within and among groups of strains of six xanthomonads and Xylella fastidiosa

\begin{tabular}{lccc}
\hline Groups of strains $^{\mathrm{a}}$ & X. albilineans & Xantho & Xylella \\
\hline I. Fragment efp & & & \\
X. albilineans & 100 & $\ldots$ & $\ldots$ \\
Xantho & $86.1-87.6$ & $94.1-98.2$ & $\ldots$ \\
Xylella & $76.2-77.0$ & $76.6-79.4$ & 98.2 \\
II. Fragment ihfA & & & \\
X. albilineans & 100 & $\ldots$ & $\ldots$ \\
Xantho & $88.6-90.0$ & $92.7-98.6$ & $\ldots$ \\
Xylella & $74.4-76.1$ & $73.4-78.5$ & 94.1 \\
III. Fragment pilB & & & \\
X. albilineans & $98.8-100$ & $\ldots$ & $\ldots$ \\
Xantho & $87.9-89.6$ & $91.6-96.0$ & $\ldots$ \\
Xylella & $78.6-79.3$ & $78.7-80.5$ & 97.7 \\
IV. Fragment rpfA $1^{\mathrm{b}}$ & & & \\
X. albilineans & $99.4-100$ & $\ldots$ & $\ldots$ \\
Xantho & $85.6-86.6$ & $91.5-97.2$ & $\ldots$ \\
Xylella & $78.7-79.3$ & $78.5-79.8$ & 98.6 \\
V. Fragment xpsE & & & \\
X. albilineans & $99.3-100$ & $\ldots$ & $\ldots$ \\
Xantho & $88.3-89.6$ & $93.7-97.2$ & $\ldots$ \\
Xylella & $75.3-75.7$ & $74.8-76.6$ & 97.0 \\
\hline X. abilineans &
\end{tabular}

${ }^{\mathrm{a}} X$. albilineans $=$ nine strains of Xanthomonas albilineans from Guadeloupe and strain Xa23R1 from Florida; Xantho = strains $X$. arboricola pv. pruni, $X$. axonopodis pv. citri, $X$. campestris pv. campestris, $X$. campestris pv. vesicatoria, and X. oryzae pv. oryzae; and Xylella = Xylella fastidiosa strain $9 \mathrm{a} 5 \mathrm{c}$ and $X$. fastidiosa strain Temecula1.

${ }^{\mathrm{b}}$ Sequence of this fragment was not available for Xanthomonas arboricola $\mathrm{pv}$. pruni. number of polymorphic bands were observed between the two independent replications of the AFLP assay. However, the number of haplotypes and strain assignment to these haplotypes did not vary, indicating reliability of the technique (data not shown). Six combined haplotypes and two major genetic groups, AFLP-A (combined haplotypes GA1 and GA2) and AFLP-B (combined haplotypes GB1 to GB4), were obtained, but no relationship with the stalk colonization groups or DS groups was found (Table 5).

Single nucleotide variations in the sequence of pathogenicityrelated genes has been shown to be responsible for variation in virulence or aggressiveness in several pathogenic microorganisms $(3,47,52)$. In bacterial plant pathogens, a wide range of pathogenicity-related genes have been identified and analyzed. These genes code for secretion system constitutive proteins, exopolysaccharides, virulence factors, toxins, plant cell-wall-degrading enzymes, cell mobility and motility factors, or adhesion factors $(21,48)$. PCR amplification with specific or degenerate primers has been used successfully to identify homologous gene sequences at pathovar or even generic levels in Pseudomonas and Xanthomonas spp. $(23,27,43)$. However, of 40 pathogenicityrelated genes from several xanthomonads or Xylella fastidiosa, only 3 (pilB, rpfA, and xpsE) were amplified in Xanthomonas albilineans. These genes all are involved in general pathogenicity mechanisms. Gene pilB codes for the type IV pilus biogenesis protein $\mathrm{B}$ involved in twitching motility, rpfA encodes an aconitase involved in the regulator system of pathogenicity factor, and $x p s E$ codes for the type II secretion system biogenesis protein $E$ involved in a general secretory pathway in several plant pathogens $(10,14,19,44)$. Additionally, among nine strains of $X$. albilineans differing in pathogenicity, no variation was found in the nucleotide sequence of these fragments. This result confirmed, at the nucleotide sequence level, the genetic uniformity of this pathogen in Guadeloupe. Absence of amplification with 37 primer combinations suggested that the corresponding genes involved in pathogenicity either are absent in X. albilineans or differ from those existing in other closely related pathogens. No amplification in $X$. albilineans of $h r c L, h r c N$, and $h r p B 7$ genes coding for essential components of the common type III secretion system in plant-pathogenic bacteria confirmed previous results (27).

Housekeeping genes are highly conserved genes and, therefore, are very useful for phylogenetic studies of a pathogen (9). The nucleotide sequence of housekeeping genes efp and ihfA did not vary among nine strains in Guadeloupe differing in pathogenicity. However, the phylogenetic study of 26 bacterial species (including $X$. albilineans) with these two housekeeping genes and

TABLE 5. Summary of genetic and pathogenic characteristics of nine strains of Xanthomonas albilineans from Guadeloupe

\begin{tabular}{lcccc}
\hline & & & \multicolumn{2}{c}{ Combined haplotype } \\
\cline { 4 - 5 } Strain $^{\mathrm{a}}$ & Stalk group $^{\mathrm{b}}$ & RFLP-PFGE $^{\mathrm{c}}$ & ALB-RFP $^{\mathrm{d}}$ & AFLP \\
\hline GPEPC17 & SCG1 & B-02 & HB2 & GA1 \\
GPEPC73 & SCG4 & B-02 & HB2 & GA2 \\
GPEPC75 & SCG3 & B-02 & HB2 & GA2 \\
GPEPC84 & SCG1 & B-02 & HB2 & GA2 \\
GPEPC86 & SCG1 & B-02 & HB2 & GB1 \\
GPEPC87 & SCG3 & B-02 & HB2 & GB2 \\
GPEPC101 & SCG1 & B-02 & HB2 & GB4 \\
GPEPC142 & SCG2 & B-02 & HB2 & GB3 \\
GPEPC143 & SCG3 & B-02 & HB2 & GB3 \\
\hline
\end{tabular}

a Origin and characteristics of strains are shown in Table 1. All strains showed an identical nucleotide sequence for housekeeping genes $e f p$ and ihfA, and pathogenicity related genes pilB, rpfA, and xpsE.

b Stalk colonization group; data from Figure 1. Disease severity groups were similar to stalk colonization groups.

${ }^{c}$ Haplotype restriction fragment length polymorphism (RFLP) pulsed-field gel electrophoresis (PFGE); from this study and Davis et al. (17).

d Albicidin (ALB)-RFLP; from this study and Champoiseau et al. (12).

e Amplified fragment length polymorphism (AFLP); this study. 
pathogenicity genes pilB, rpfA, and $x p s E$ confirmed that $X$. albilineans was closest to the $X$. campestris group (34), but showed also that $X$. albilineans was related to $X$. fastidiosa, another xylem pathogen that does not possess any avr or hrp genes (44). Very little information is available presently regarding genes involved in pathogenicity of Xylella fastidiosa; however, based on their phylogenetic positions, it can be hypothesized that Xanthomonas albilineans and this pathogen share common genetic features, including those involved in pathogenicity.

Autoinduction, or quorum sensing, is a feature of virulence of plant-pathogenic bacteria that involves secretion and detection of small, diffusible signal molecules that permit cell-to-cell communication and allows bacteria to assess their local population density or physical confinement (49). Traits regulated by quorum sensing include the production of extracellular polysaccharides, degradative enzymes, antibiotics, siderophores, and pigments, as well as Hrp protein secretion, Ti plasmid transfer, motility, biofilm formation, and epiphytic fitness (49). AHLs are the most commonly reported type of quorum-sensing signals. No evidence of AHL production was detected in nine strains of $X$. albilineans from Guadeloupe differing in pathogenicity. Similarly, no AHL production was found in two and seven different pathovars of $X$. oryzae and $X$. campestris, respectively (11). However, it cannot be excluded that other quorum-sensing or cell-to-cell communication-diffusible signal molecules play a role in the regulation of several pathogenicity traits in $X$. albilineans. These molecules may explain, at least in part, variation in pathogenicity of $X$. albilineans, as was shown recently for $X$. campestris pv. campestris (50).

In conclusion, the origin of variation in pathogenicity of genetically closely related strains of $X$. albilineans remains to be deciphered. Genetic uniformity of strains of this pathogen differing in pathogenicity was observed at different genetic levels, from the whole genome to specific nucleotide sequences. However, only a small part of the genome has been investigated in details. Because no large deletion or insertion was detected between the genomes of $X$. albilineans pathotypes, apart from complex nongenetic regulatory systems not identified so far in this pathogen, single nucleotide mutations in one or more genes involved in pathogenicity of $X$. albilineans most likely are responsible for variation in pathogenicity of $X$. albilineans. Therefore, analysis of the complete genome sequence of $X$. albilineans and comparison with genome sequences of other phytopathogenic bacteria might be the next step in the identification of pathogenicity genes in this pathogen. Sequencing of the genome of $X$. albilineans strain GPEPC73, isolated in this study, is in progress at Genoscope (Evry, France). Obtaining the entire genome sequence of this pathogen will lead to a significant breakthrough in the characterization of the molecular mechanisms involved in the sugarcane-X. albilineans interaction.

\section{ACKNOWLEDGMENTS}

This work was supported in part by the "Conseil Régional de Guadeloupe" and the "Fonds Social Européen". We thank R. Boisne-Noc, S. Duplan, S. Joseph, L. Toubi, and E. Vivien for technical assistance and advice; S. Boudon for supplying efp oligonucleotides; S. K. Farrand for supplying AHL biosensor strains; D. W. Gabriel for supplying Xylella fastidiosa DNA; A. R. Poplawsky for supplying PigB DF biosensor strains; and M. J. Davis for critical review of the manuscript.

\section{LITERATURE CITED}

1. Astua-Monge, G., Minsavage, G. V., Stall, R. E., Davis, M. J., Bonas, U., and Jones, J. B. 2000. Resistance of tomato and pepper to T3 strains of Xanthomonas campestris pv. vesicatoria is specified by a plant-inducible avirulence gene. Mol. Plant-Microbe Interact. 13:911-921.

2. Autrey, L. J. C., Saumtally, S., Dookun, A., Sullivan, S., and Dhayan, S. 1995. Aerial transmission of the leaf scald pathogen, Xanthomonas albilineans. Proc. Int. Soc. Sugar Cane Technol. 21:508-526.
3. Bender, C. L., Alarcon-Chaidez, F., and Gross, D. C. 1999. Pseudomonas syringae phytotoxins: Mode of action, regulation, and biosynthesis by peptide and polyketide synthetases. Microbiol. Mol. Biol. Rev. 63:266292.

4. Birch, R. G. 2001. Xanthomonas albilineans and the antipathogenesis approach to disease control. Mol. Plant Pathol. 2:1-11.

5. Birch, R. G., and Patil, S. S. June 1985. Antibiotic and process for the production thereof. U. S. patent 4,525,354.

6. Birch, R. G., and Patil, S. S. 1985. Preliminary characterization of an antibiotic produced by Xanthomonas albilineans which inhibits DNA synthesis in Escherichia coli. J. Gen. Microbiol. 131:1069-1075.

7. Birch, R. G., and Patil, S. S. 1987. Correlation between albicidin production and chlorosis induction by Xanthomonas albilineans, the sugarcane pathogen. Physiol. Mol. Plant Pathol. 30:199-206.

8. Birch, R. G., and Patil, S. S. 1987. Evidence that an albicidin-like phytotoxin induces chlorosis in sugarcane leaf scald disease by blocking plastid DNA replication. Physiol. Mol. Plant Pathol. 30:207-214.

9. Boudon, S., Manceau, C., and Nottéghem, J.-L. 2005. Structure and origin of Xanthomonas arboricola pv. pruni populations causing bacterial spot of stone fruit trees in Western Europe. Phytopathology 95:10811088.

10. Cao, H., Baldini, R. L., and Rahme, L. G. 2001. Common mechanisms for pathogens of plants and animals. Annu. Rev. Phytopathol. 39:259-284.

11. Cha, C., Gao, P., Chen, Y.-C., Shaw, P. D., and Farrand, S. K. 1998. Production of acyl-homoserine lactone quorum-sensing signals by gramnegative plant-associated bacteria. Mol. Plant-Microbe Interact. 11:11191129.

12. Champoiseau, P., Daugrois, J.-H., Girard, J.-C., Royer, M., and Rott, P. 2006. Variation in albicidin biosynthesis genes and in pathogenicity of Xanthomonas albilineans, the sugarcane leaf scald pathogen. Phytopathology 96:33-45.

13. Comstock, J. C. 2001. Foliar symptoms of sugarcane leaf scald. Sugar J. 64:23-32.

14. Da Silva, A. C. R., Ferro, J. A., Reinach, F. C., Farah, C. S., Furlan, L. R., Quaggio, R. B., Monteiro-Vitorello, C. B., Van Sluys, M. A., Almeida, N. F., Alves, L. M. C., do Amaral, A. M., Bertolini, M. C., Camargo, L. E. A., Camarotte, G., Cannavan, F., Cardozo, J., Chambergo, F., Ciapina, L. P., Cicarelli, R. M. B., Coutinho, L. L., Cursino-Santos, J. R., El-Dorry, H., Faria, J. B., Ferreira, A. J. S., Ferreira, R. C. C., Ferro, M. I. T., Formighieri, E. F., Franco, M. C., Greggio, C. C., Gruber, A., Katsuyama, A. M., Kishi, L. T., Leite, R. P., Lemos, E. G. M., Lemos, M. V. F., Locali, E. C., Machado, M. A., Madeira, A. M. B. N., Martinez-Rossi, N. M., Martins, E. C., Meidanis, J., Menck, C. F. M., Miyaki, C. Y., Moon, D. H., Moreira, L. M., Novo, M. T. M., Okura, V. K., Oliveira, M. C., Oliveira, V. R., Pereira, H. A., Rossi, A., Sena, J. A. D., Silva, C., de Souza, R. F., Spinola, L. A. F., Takita, M. A., Tamura, R. E., Teixeira, E. C., Tezza, R. I. D., Trindade dos Santos, M., Truffi, D., Tsai, S. M., White, F. F., Setubal, J. C., and Kitajima, J. P. 2002. Comparison of the genomes of two Xanthomonas pathogens with differing host specificities. Nature 417:459463.

15. Daugrois, J. H., Dumont, V., Champoiseau, P., Costet, L., Boisne-Noc, R., and Rott, P. 2003. Aerial contamination of sugarcane in Guadeloupe by two strains of Xanthomonas albilineans. Eur. J. Plant Pathol. 109: 445-458.

16. Davis, M. J., Rott, P., Baudin, P., and Dean, J. L. 1994. Evaluation of selective media and immunoassays for detection of Xanthomonas albilineans, causal agent of sugarcane leaf scald disease. Plant Dis. 78:78-82.

17. Davis, M. J., Rott, P., Warmuth, C. J., Chatenet, M., and Baudin, P. 1997. Intraspecific genomic variation within Xanthomonas albilineans, the sugarcane leaf scald pathogen. Phytopathology 87:316-324.

18. Diaz, M., Peralta, E. L., Iglesias, A., Pazos, V., Carvajal, O., Perez, J., Gigliotti, E. A., Gagliardi, P. R., Wendland, A., and Camargo, L. E. A. 2001. Xanthomonas albilineans haplotype B responsible for a recent sugarcane leaf scald disease outbreak in Cuba. Plant Dis. 85:334.

19. Dow, J. M., Feng, J.-X., Barber, C. E., Tang, J.-L., and Daniels, M. J. 2000. Novel genes involved in the regulation of pathogenicity factor production within the rpf gene cluster of Xanthomonas campestris. Microbiology 146:885-891.

20. Feldmann, P., Sapotille, J., Grédoire, P., and Rott, P. 1994. Micropropagation of sugarcane. Pages 15-17 in: In vitro Culture of Tropical Plants. C. Teisson, ed. La Librairie du Cirad, Montpellier, France.

21. Genin, S., and Boucher, C. 2004. Lessons learned from the genome analysis of Ralstonia solanacearum. Annu. Rev. Phytopathol. 42:107-134.

22. Gonzalez, C., Restrepo, S., Tohme, J., and Verdier, V. 2002. Characterization of pathogenic and nonpathogenic strains of Xanthomonas axonopodis pv. manihotis by PCR-based DNA fingerprinting techniques. FEMS Microbiol. Lett. 215:23-31.

23. Gropp, S. J., and Guttman, D. S. 2004. The PCR amplification and characterization of entire Pseudomonas syringae hrp/hrc clusters. Mol. Plant Pathol. 5:137-140. 
24. Horita, M., and Tsuchiya, K. 2000. Genetic diversity of Japanese strains of Ralstonia solanacearum. Phytopathology 91:399-407.

25. Jukes, T. H., and Cantor, C. R. 1969. Evolution of protein molecules. Pages 21-132 in: Mammalian Protein Metabolism. H. N. Munro, ed. Academic Press, New York.

26. Koike, H. 1965. The aluminum cap method for testing sugarcane varieties against leaf scald disease. Phytopathology 55:317-319.

27. Leite, R. P. J., Minsavage, G. V., Bonas, U., and Stall, R. E. 1994. Detection and identification of phytopathogenic Xanthomonas strains by identification of DNA sequences related to the hrp genes of Xanthomonas campestris pv. vesicatoria. Appl. Environ. Microbiol. 60:1068-1077.

28. Mohamed, I. S., Rott, P., Davis, M. J., and Chatenet, M. 1996. Differentiation of Xanthomonas albilineans strains based on multiplication of the pathogen in sugarcane varieties. Proc. Int. Soc. Sugar Cane Technol. 22:486-492.

29. Mundt, C. C., Nieva, L. P., and Vera Cruz, C. M. 2002. Variation for aggressiveness within and between lineages of Xanthomonas oryzae pv. oryzae. Plant Pathol. 51:163-168.

30. Nelson, R. J., Baraoidan, M. R., Vera Cruz, C. M., Yap, I. V., Leach, J. E., Mew, T. W., and Leung, H. 1994. Relationship between phylogeny and pathotype for the bacterial pathogen of rice. Appl. Environ. Microbiol. 60:3275-3283.

31. Pilet, F., Clerc, F., Royer, M., Chatenet, M., Trigalet-Demery, D., and Rott, P. 2000. Différenciation des Xanthomonas pathogènes de la canne à sucre par RFLP et AFLP. Page 48 in: Résumés des Quatrièmes Rencontres de Phytobactériologie. CNRS/INRA, Aussois, France.

32. Poplawsky, A. R., and Chun, W. 1997. pigB determines a diffusible factor needed for extracellular polysaccharide slime and Xanthomonadin production in Xanthomonas campestris pv. campestris. J. Bacteriol. 179:439-444.

33. Poussier, S., Trigalet-Demery, D., Vandewalle, P., Goffinet, B., Luisetti, J., and Trigalet, A. 2000. Genetic diversity of Ralstonia solanacearum as assessed by PCR-RFLP of the hrp gene region, AFLP and 16S rRNA sequence analysis, and identification of an African subdivision. Microbiology 146:1679-1692.

34. Rademaker, J. L. W., Louws, F. J., Schultz, M. H., Rossbach, U., Vauterin, L., Swings, J., and de Bruijn, F. J. 2005. A comprehensive species to strain taxonomic framework for Xanthomonas. Phytopathology 95:1098-1111.

35. Rott, P., Chatenet, M., Granier, M., and Baudin, P. 1988. L'échaudure des feuilles de la canne à sucre provoquée par Xanthomonas albilineans (Ashby) Dowson. II. Diagnostic et spectres d'hôtes de l'agent pathogène en Afrique tropicale. Agron. Trop. (Paris) 43:244-252.

36. Rott, P., Costet, L., Davis, M. J., Frutos, R., and Dean, G. 1996. At least two separate gene clusters are involved in albicidin production by Xanthomonas albilineans. J. Bacteriol. 178:4590-4596.

37. Rott, P., and Davis, M. J. 1996. Recent advances in research on variability of Xanthomonas albilineans, causal agent of sugarcane leaf scald disease. Proc. Int. Soc. Sugar Cane Technol. 22:498-504.

38. Rott, P., and Davis, M. J. 2000. Leaf scald. Pages 38-44 in: A Guide to Sugarcane Diseases. P. Rott, R. A. Bailey, J. C. Comstock, B. J. Croft, and A. S. Saumtally, eds. La librairie du Cirad, Montpellier, France.

39. Rott, P., Davis, M. J., and Baudin, P. 1994. Serological variability in Xanthomonas albilineans, causal agent of leaf scald disease of sugarcane. Plant Pathol. 43:344-349.

40. Rott, P., Mohamed, I. S., Klett, P., Soupa, D., de Saint-Albin, A., Feldmann, P., and Letourmy, P. 1997. Resistance to leaf scald disease is associated with limited colonization of sugarcane and wild relatives by Xanthomonas albilineans. Phytopathology 87:1202-1213.

41. Royer, M., Costet, L., Vivien, E., Bes, M., Cousin, A., Damais, A., Pieretti, I., Savin, A., Megessier, S., Viard, M., Frutos, R., Gabriel, D. W., and Rott, P. 2004. Albicidin pathotoxin produced by Xanthomonas albilineans is encoded by three large PKS and NRPS genes present in a gene cluster also containing several putative modifying, regulatory, and resistance genes. Mol. Plant-Microbe Interact. 17:414-427.
42. Sambrook, J., Fritsch, E. F., and Maniatis, T. 1989. Molecular Cloning: A Laboratory Manual. 2nd ed. Cold Spring Harbor Laboratory, Cold Spring Harbor, NY.

43. Seal, S. E., Jackson, L. A., and Daniels, M. J. 1992. Isolation of a Pseudomonas solanacearum-specific DNA probe by subtraction hybridization and construction of species-specific oligonucleotide primers for sensitive detection by the polymerase chain reaction. Appl. Environ. Microbiol. 58:3751-3758.

44. Simpson, A. J. G., Reinach, F. C., Arruda, P., Abreu, F. A., Acencio, M., Alvarenga, R., Alves, L. M. C., Araya, J. E., Baia, G. S., Baptista, C. S., Barros, M. H., Bonaccorsi, E. D., Bordin, S., Bové, J. M., Briones, M. R. S., Bueno, M. R. P., Camargo, A. A., Camargo, L. E. A., Carraro, D. M., Carrer, H., Colauto, N. B., Colombo, C., Costa, F. F., Costa, M. C. R., Costa-Neto, C. M., Coutinho, L. L., Cristofani, M., Dias-Neto, E., Docena, C., El-Dorry, H., Facincani, A. P., Ferreira, A. J. S., Ferreira, V. C. A., Ferro, J. A., Fraga, J. S., França, S. C., Franco, M. C., Frohme, M., Furlan, L. R., Garnier, M., Goldman, G. H., Goldman, M. H. S., Gomes, S. L., Gruber, A., Ho, P. L., Hoheisel, J. D., Junqueira, M. L., Kemper, E. L., Kitajima, J. P., Krieger, J. E., Kuramae, E. E., Laigret, F., Lambais, M. R., Leite, L. C. C., Lemos, E. G. M., Lemos, M. V. F., Lopes, S. A., Lopes, C. R., Machado, J. A., Machado, M. A., Madeira, A. M. B. N., Madeira, H. M. F., Marino, C. L., Marques, M. V., Martins, E. A. L., Martins, E. M. F., Matsukuma, A. Y., Menck, C. F. M., Miracca, E. C., Miyaki, C. Y., Monteiro-Vitorello, C. B., Moon, D. H., Nagai, M. A., Nascimento, A. L. T. O., Netto, L. E. S., Nhani, A., Nobrega, F. G., Nunes, L. R., Oliveira, M. A., de Oliveira, M. C., de Oliveira, R. C., Palmieri, D. A., Paris, A., Peixoto, B. R., Pereira, G. A. G., Pereira, H. A., Pesquero, J. B., Quaggio, R. B., Roberto, P. G., Rodrigues, V., de M. Rosa, A. J., de Rosa, V. E., de Sá, R. G., Santelli, R. V., Sawasaki, H. E., da Silva, A. C. R., da Silva, A. M., da Silva, F. R., Silva, W. A., da Silveira, J. F., Silvestri, M. L. Z., Siqueira, W. J., de Souza, A. A., de Souza, A. P., Terenzi, M. F., Truffi, D., Tsai, S. M., Tsuhako, M. H., Vallada, H., Van Sluys, M. A., Verjovski-Almeida, S., Vettore, A. L., Zago, M. A., Zatz, M., Meidanis, J., and Setubal, J. C. 2000. The genome sequence of the plant pathogen Xylella fastidiosa. Nature 406:151-157.

45. Sneath, P. H. A., and Sokal, R. R. 1973. Numerical Taxonomy: The Principles and Practice of Numerical Classification, W. H. Freeman and Co., San Francisco.

46. Titarenko, E., Lopez-Solanilla, E., Garcia-Olmedo, F., and RodriguezPalenzuela, P. 1997. Mutants of Ralstonia (Pseudomonas) solanacearum sensitive to antimicrobial peptides are altered in their lipopolysaccharide structure and are avirulent in tobacco. J. Bacteriol. 179:6699-6704.

47. Van den Broek, P., Pittet, A., and Hajjaj, H. 2001. Aflatoxin genes and the aflatoxigenic potential of Koji moulds. Appl. Microbiol. Biotechnol. 57:192-199.

48. Van Sluys, M. A., Monteiro-Vitorello, C. B., Camargo, L. E. A., Menck, C. F. M., da Silva, A. C. R., Ferro, J. A., Oliveira, M. C., Setubal, J. C., Kitajima, J. P., and Simpson, A. J. 2002. Comparative genomic analysis of plant-associated bacteria. Annu. Rev. Phytopathol. 40:169-189.

49. Von Bodman, S. B., Bauer, W. D., and Coplin, D. L. 2003. Quorum sensing in plant-pathogenic bacteria. Annu. Rev. Phytopathol. 41:455482.

50. Wang, L.-H., He, Y., Gao, Y., Wu, J. E., Dong, Y.-H., He, C., Wang, S. X., Weng, L.-X., Xu, J.-L., Tay, L., Fang, R. X., and Zhang, L.-H. 2004. A bacterial cell-cell communication signal with cross-kingdom structural analogues. Mol. Microbiol. 51:903-912.

51. Ward, J. H. 1963. Hierarchical grouping to optimize an objective function. Am. Stat. Assoc. J. 58:236-244.

52. Weiland, J. J., and Edwards, M. C. 1996. A single nucleotide substitution in the alpha-a gene confers oat pathogenicity to barley stripe mosaic virus strain ND18. Mol. Plant-Microbe Interact. 9:62-67.

53. Zhang, L., Xu, J., and Birch, R. G. 1999. Engineered detoxification confers resistance against a pathogenic bacterium. Nat. Biotechnol. 17:10211024. 